\title{
Smart Chicken Coop Control and Monitoring System Design Automatically with Smartphone Notifications
}

\author{
Sri Novida Sari ${ }^{*}$, Romulo Aritonang ${ }^{2}$, Sumarlin $^{3}$ \\ ${ }_{1,2,3}$ InstitutTeknologi dan Bisnis Indonesia, Indonesia \\ ${ }^{1}$ srinovidasari@gmail.com, ${ }^{2}$ romuloaritonang@yahoo.com, ${ }^{3}$ netcommandiri@gmail.com
}

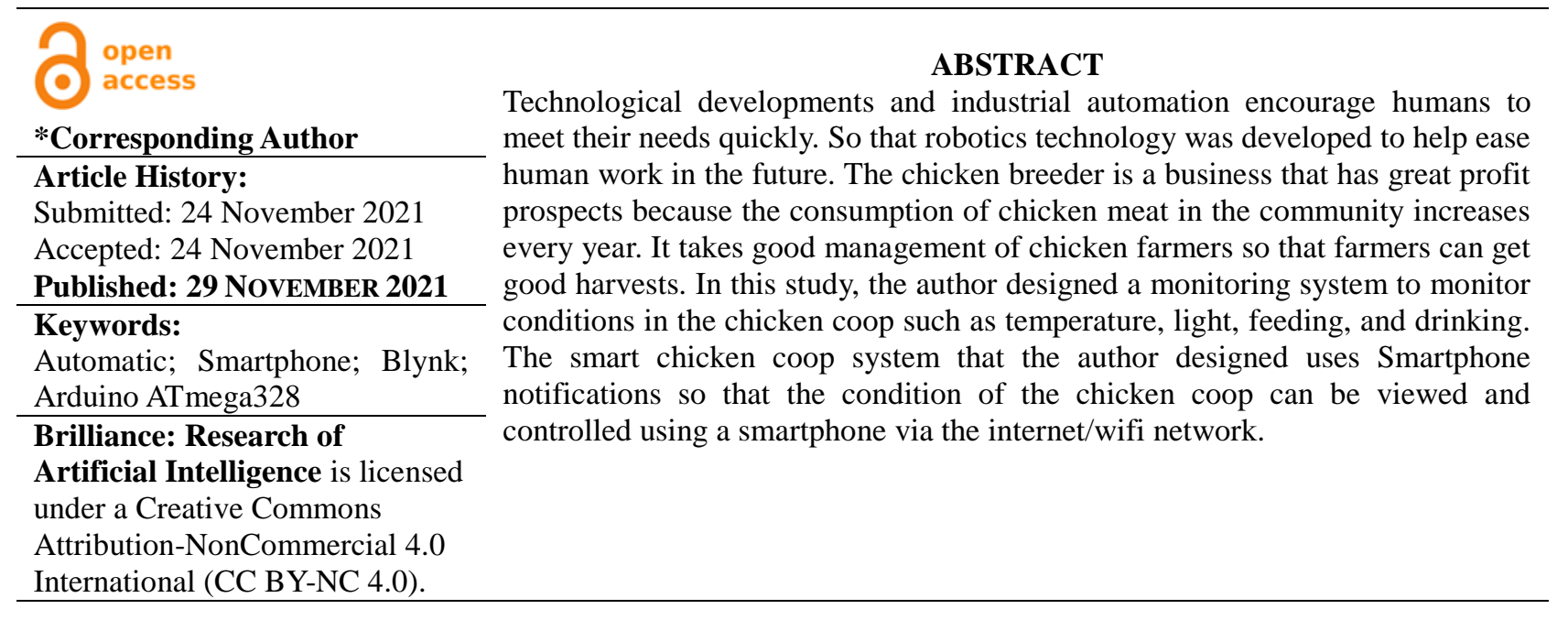

\section{INTRODUCTION}

The development of increasingly advanced technology makes people expect convenience in various aspects of life. One of them is entrepreneurship so that businesses can be run efficiently, practically, and effectively. One of the entrepreneurship is in the field of chicken farming, in general, breeders still manually feed the chickens that are kept. They use their hands to spread the feed on the feed container and walk along the cage. With such a large cage, of course, it is not easy to carry out periodic monitoring quickly on the condition of the cage. The temperature and humidity in the cage also require rapid monitoring because these two parameters are easy to change. From the above problems, an idea emerged to make a special cage for chickens that can control temperature, feed, and drink automatically. Where in controlling the temperature if the weather conditions are hot then the temperature turns cold and if the weather conditions are cold then the temperature will be hot. Meanwhile, feeding and drinking are done automatically using Real-Time Clock. If the specified time has been fulfilled, the servo motor will move to open the feed container, and if the specified time has elapsed, the servo motor will close the feed container.

In this case, the author wants to create a system that can make it easier for chicken breeders to be able to control the situation and control smart chicken coops every time. That is operated automatically by using Smartphone notifications. With this, the system created will be in the form of an automatic tool where the tool will be able to help the owner of the chicken farmer to control the situation of the smart chicken coop through Smartphone notifications. So that the system created by the author will make it easier for chicken farmers.

Regarding the Design of Control Systems and Monitoring of Smart Chicken Coops Automatically With Smartphone Notifications equipped with systems to inform data on drinking water running out and feeding, drinking with Smartphone notifications that have been examined, among others: Ari Ajibekti Masriwilaga, Tubagus Abdul Jabar, Agus Subagja, Sopian Septiana ( 2019), This study only discusses temperature and humidity detectors. The same research was also discussed by Margaretha Yohanna, Desy Tri Natasia Lumban Toruan (2018), in Designing an Automatic Feeding and Drinking System. This study only discusses automatic feeding and drinking. Furthermore, in a similar study by Prasetio, Stephanus, AZ, Nazori (2019), automatic temperature control was explained.

Based on these observations, the author wants to design a system that has the advantages of existing journal titles by combining all existing systems such as temperature and humidity detectors, automatic feeding and drinking, and the addition of incandescent lamps. complement the existing system, namely the design of control and monitoring systems, sometimes smart chickens automatically.

\section{LITERATURE REVIEW}

Control system or control system (control system) can be interpreted as a collection of tools to control, regulate and regulate the state of a system. Where the system can work if given an order by the controller. So that it can be said that control is a process in directing variables to achieve and targets that have been previously set. 


\section{Smart Chicken Cage}

The cage can be thought of as a structure or facility where livestock are kept in simple words. Cages are sometimes divided into three types based on the number of animals housed in them: one building for one animal, one building with numerous animals but separated by partitions, and one structure with many animals but no partitions. In Indonesian, a cage is a generic term, but English has a variety of terms that are often differentiated based on the type of animal kept and how it is kept. maintenance.

\section{Smartphone}

A smartphone can be defined as a mobile phone or smart cellular phone equipped with the latest features and high capabilities like a computer. A smartphone can also be interpreted as a mobile phone that works using operating system (OS) software that provides standard and basic relationships for application developers. Some define a smartphone as a smart mobile phone that has advanced features such as Email, the Internet, and others. phone, the smartphone is a small computer that has the capabilities of a telephone.

According to Yuli Sawitri, DKK (2019:693), "Smartphones are mobile phones that can use and function that resembles a computer". ("Impact of Smartphone Use on Early Childhood Development, Banyumas Regency 2019").

According to David Wood, (2019:693), "Smartphones are mobile phones that have advantages over other telecommunication tools. The advantages can be seen from the manufacturing process and the process of using it. ("Impact of Smartphone Use on Early Childhood Development, Banyumas Regency2019").

\section{Microcontroller Atmega328}

According to Sidauruk (2017: 391) "Microcontroller is an IC chip where there is a microprocessor and program memory (called: ROM) and multipurpose memory (called: RAM), there are even several types of microcontrollers that have ADC, PLL, EEPROM facilities, in a package. " "(Implementation of the Atmega 8535 Microcontroller Based on Ultrasonic Sensors for Integrated Security Protection, Sidauruk, Riki Ardi Yosua, Simamora, and Marlindia Ike Sari, National Conference on ICT-M Telkom Polytechnic 389-395)".

According to Mustaziri, Yulian Mirza, Hartati Deviana (2020:13) "A microcontroller is a small computer ("special purpose computers") in one IC containing a CPU, memory, timer, serial and parallel communication channels, I/O ports, ADC. Microcontroller is used for a task and run a program. "(Informatics No.1 Vol 4 ISSN : 28007-5266, Palembang)".

According to Destiarini, Pius Widya Kumara (2019:20) "A microcontroller is a chip in the form of an IC (Integrated Circuit) that can receive input signals, manage them and provide output signals according to the program entered into it. The microcontroller input signal comes from the sensor which is information from the environment while the output signal is given to the actuator which can affect the environment." (Robot Line Pollower Based on Arduino Uno Atmega 328 Microcontroller, Journal of Informatics, Volume 5 No. : 2407-1730)".

The microcontroller is a chip that functions as an electronic circuit controller and generally can store programs in it. Microcontrollers generally consist of a CPU (Central Processing Unit), certain I/O memory, and supporting units such as Analog-to-Digital Converter (ADC) which are already integrated with it. The main advantage of the microcontroller is the availability of RAM and I / O equipment so that the size of the microcontroller board becomes very short.

\section{Light Sensor}

A light sensor is defined as a device or component that functions to convert light energy, either visible or infrared light, into electrical energy. This tool is capable of detecting the presence of light and then processing it into an electrical signal for use in a circuit that uses light as a trigger.

According to Erni Setyaningsih, Dhidik Prastiyanto, Suryono (2017:55) "Light sensors are electronic components that function to convert an optical quantity (light) into an electrical quantity. Light sensors based on the electrical changes produced are divided into two types, namely photovoltaic and photoconductive. "(Use of Photodiode Sensors as a Fire Detection System on Vertical Take-Off Landing (VTOL) Flying Vehicles, Journal of Electrical Engineering Vol.9 No.2 June-December 2017 P-ISSN 1411-0059 E-ISSN 2549-1571, Semarang)".

According to Febyano Ilham Dwinata, Ikah Ning Prasetyowati Permanasari, Mahardika Yoga Darmawan (2019:3) "Light sensors are electronic components that convert physical quantities, in this case, light into electrical quantities. The type of light sensor used in this study is BH1750. This sensor works based on the amount of light intensity received by the sensor and produces a sensor value in the form of an intensity value in lux units. 


\section{Temperature Sensor}

A temperature sensor is defined as a device used to convert heat into electrical quantities that can be analyzed by magnitude. There are several methods used to make this sensor, one of which is by using a material that can withstand electric current according to its temperature.

\section{Proximity Sensor}

Proximity sensors are defined as sensors or scalars that can detect the presence of metallic targets without any physical contact, proximity sensors are devices that detect the presence and proximity of objects, both metallic and nonmetallic.

According to Muhammad Rifan (2019:23) "Proximity sensors are sensors that are used to sense the proximity of an object relative to other objects." Below is an image of the Proximity sensor. (Sensor Module: Digital Control and IoT, Muhammad Rifan Publisher).

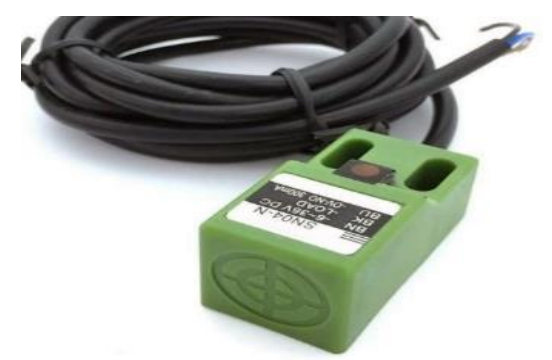

Figure 1. Proximity Sensor

\section{Water Level Sensor}

According to Mochamad Fajar Wicaksono (2019: 181), "The water level sensor is a sensor used to control the water level. This sensor can be applied to aquaponics, hydroponics and other projects." (Arduino and Sensor applications are accompanied by 32 projects and 5 Robot projects, Bandung Informatics, Bandung). Below is a picture of the water level sensor.

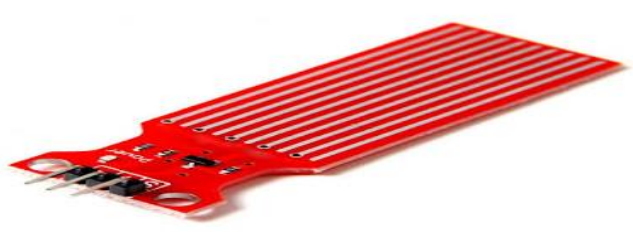

Figure 2. Water Level Sensor

\section{METHOD}

\section{System Analysis}

So far, the system of feeding and drinking livestock that is used is still mostly manual, or using human labor will require a lot of time and is inefficient.

From this analysis, the author tries to find a solution to facilitate the work of feeding and drinking so that it is more efficient, namely designing a smart chicken coop control and monitoring system automatically with Smartphone notifications. Where in feeding using RTC (Real Time Clock) means that with the RTC (Real Time Clock), the time that determines the system in feeding livestock.

\section{System planning}

In the hardware system design process, a block diagram has been described which explains the basic description of the system to be designed. Each block diagram has its function. The block diagram of the designed system is as shown in the following figure: 


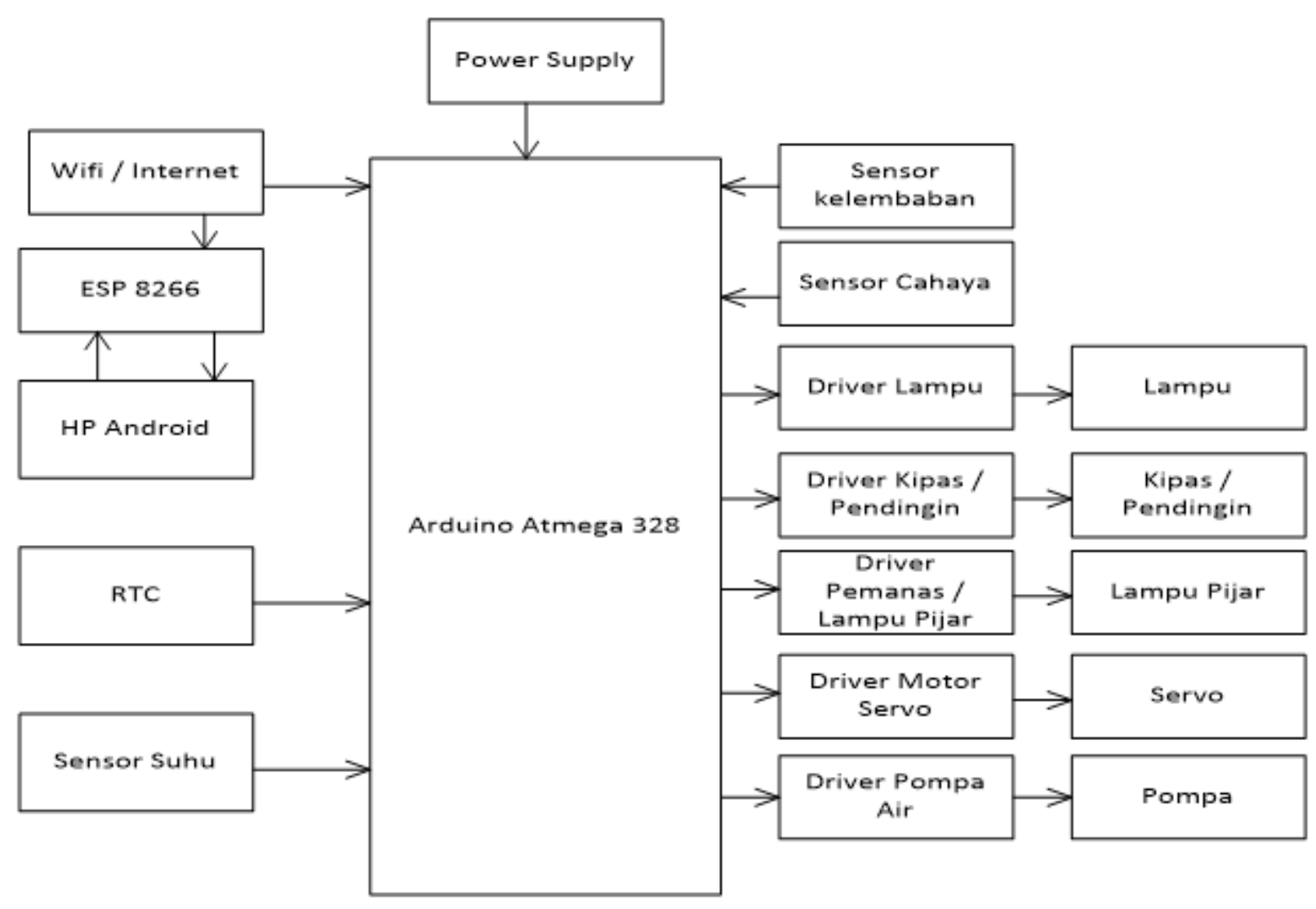

Figure 3. Hardware Design Block Diagram

The ATMega328 microcontroller is written using Arduino IDE 1.6 software after the program has been written, the entire program content has been entered into the microcontroller chip through the interface with the computer. So that all programs have been entered and can be read by the microcontroller, and then from the program, the microcontroller can control the system according to the program instructions given/entered.

The microcontroller is an IC (Integrated Circuit) which contains complex logic circuits to perform actions. The microcontroller has a memory so that it can store programs for control.

A new Microcontroller is still empty memory because it needs to be filled in the program to be used. On Arduino there is a special program for data communication as well as for translating the Arduino programming language, this program is called the bootloader. The bootloader serves to bridge Arduino programs made with ATMega hardware as well as the operating system on a computer that bridges its hardware and software. Therefore, for a microcontroller to function as an Arduino, it must first enter the appropriate bootloader. The bootloader can automatically be inserted into the Microcontroller using the Arduino IDE. 
The manufacturing flow chart of the designed system is shown in the following figure:

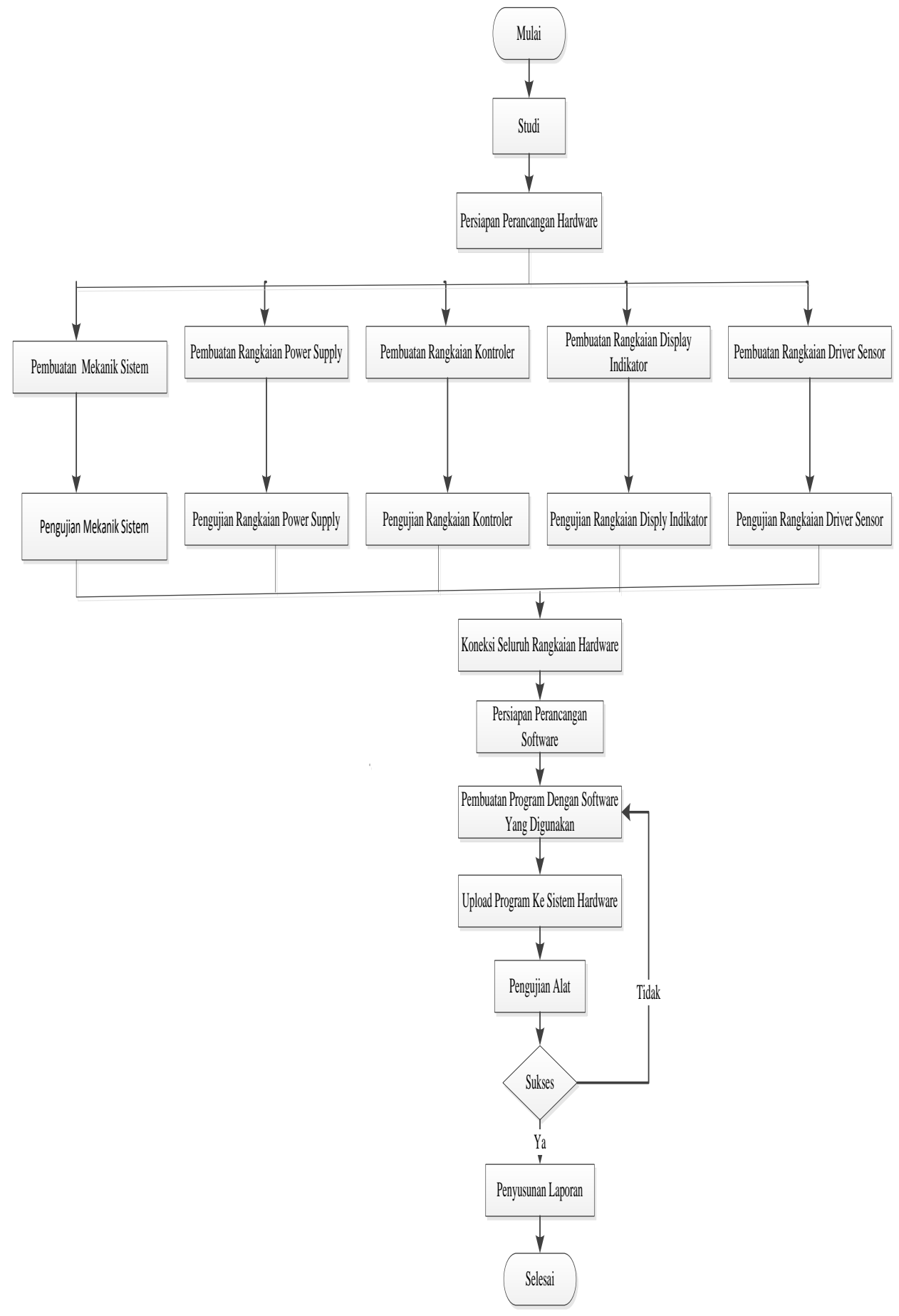

Figure 4. Flowchart Diagrams

RESULT

Based on the design results from the system analysis stage, system design/design, and system testing and the overall tool work system, both hardware and software have been tested in the robotics lab of the Indonesian Institute of Technology and Business and can function as desired, with the following results:

1. The temperature sensor is designed to detect the temperature in the chicken coop.

2. The light sensor is designed to detect the intensity of light in the chicken coop. 
3. The Proximity sensor is designed to detect the presence of feed that has been filled in the feed container through the feed tube.

4. The Water Level Sensor is designed to detect the level of fullness of water in the water reservoir.

5. The RTC (Real Time Clock) system is designed to function as a timer.

6. The servo motor is designed to act as an open and close driver in the chicken feed container.

7. A smartphone that serves as a notification when food and drink have run out.

8. The Selenoid Valve is designed to act as a valve to control the flow of water in the water reservoir.

9. The design of the software system on the ATMega328 microcontroller serves to convert the sensor readings.

Based on the results of the design above, for more detail the results of the overall test design of the control system and monitoring of smart chicken coops automatically with Smartphone notifications can be explained as follows:

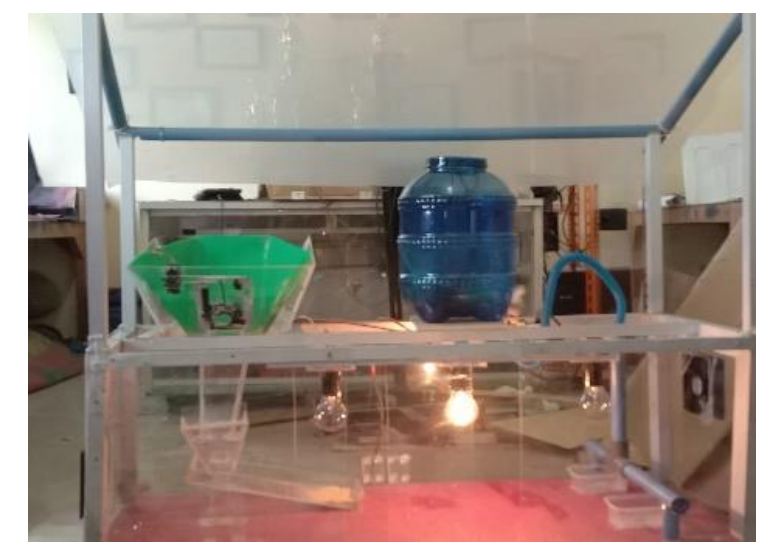

Figure 5. Front View of Smart Chicken Cage Control and Monitoring System Design

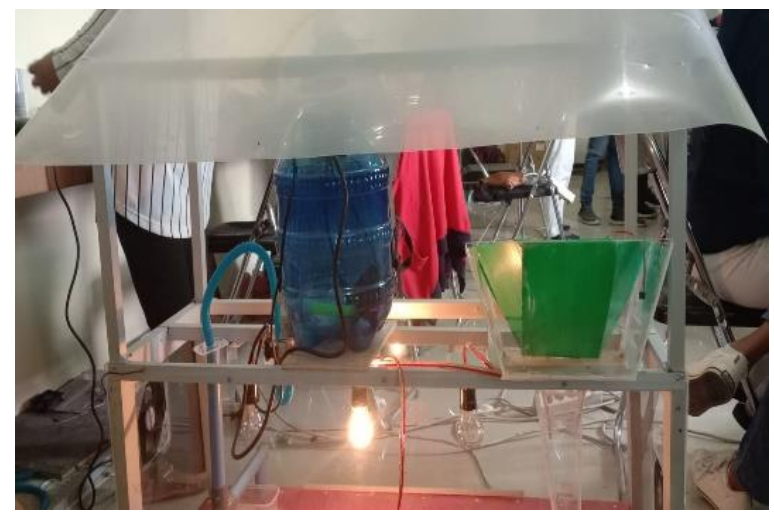

Figure 6. Back View Intelligent Chicken Coop Control and Monitoring System Design

Some Tests as a whole are:

- Servo Motor Test

When removing feed that is in the feed container using a servo motor that works automatically then the servo motor will be closed again automatically after being detected by the proximity sensor that the chicken feed is full. As shown in Figure 5. Display when servo motor is open. 


\section{Brilliance}

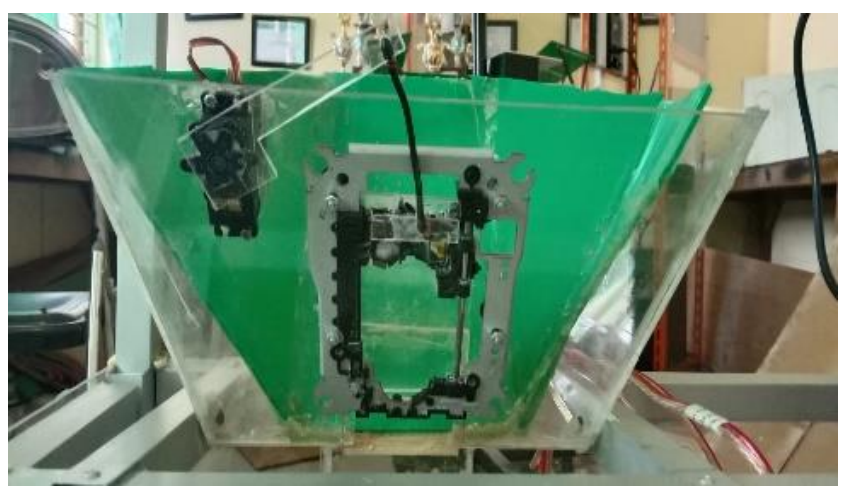

Figure 7. Display When The Servo Motor Is Open

- Water Level Sensor Test

Water Level Sensor is a tool used to turn off or turn on the water pump automatically if the water starts to run out or is almost full. When the water volume increases or the water is sufficient, the water faucet will automatically close. Shown in the image below:

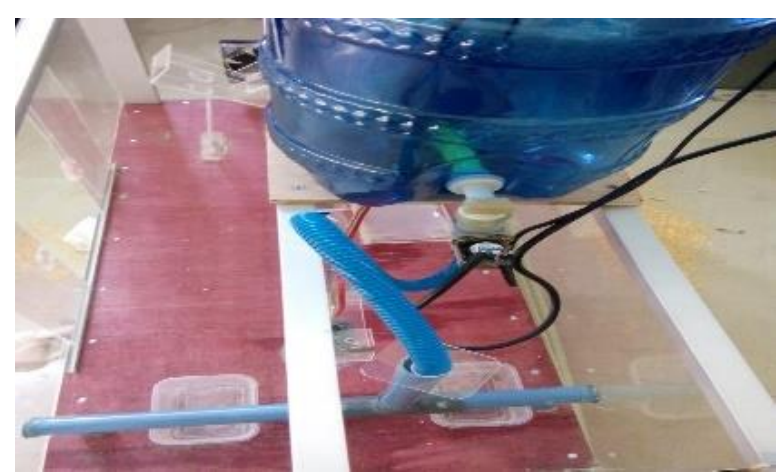

- Light Sensor Test

Figure 8. Water Level Sensor Display

The light sensor is used when the light intensity is reduced and to support the chicken coop or dim the light according to the light conditions in the chicken coop environment. As well as making it easier for chicks to recognize where to feed and drink, thus triggering eating activities and spurring growth in chickens.

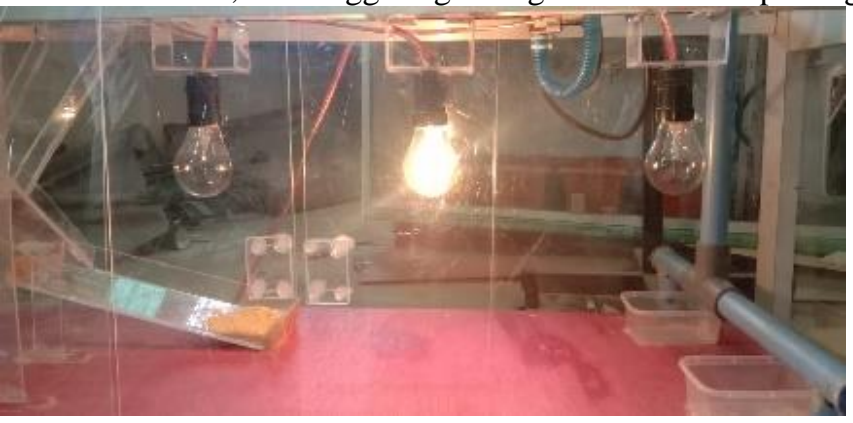

Figure 9. Light Sensor Display

- Sensor Proximity Test

The Proximity sensor functions as a detector of the presence of feed that has been filled in the feed container, through the feed feeding tube. The way to use it is when the proximity sensor detects the full feed in the container, the servo motor will automatically close the door of the chicken feed storage container. 


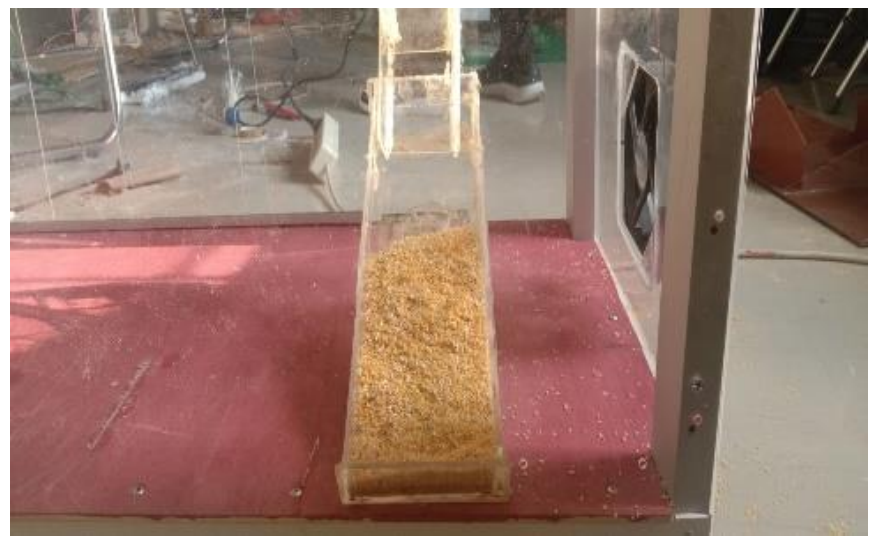

Figure 10. Proximity Sensor Display

\section{DISCUSSION}

Intelligent Chicken Coop Testing and Automatic Monitoring System Design with Smartphone Notifications, each tool or component that is used has been tested, such as testing light sensors, temperature sensors, Proximity sensors, and water sensors and the results are that all components work well.

\section{CONCLUSION}

The conclusions from the observations made on the thesis entitled Design of a smart chicken coop control and monitoring system automatically with Smartphone notifications are as follows:

1. The design of the Smart Chicken Cage Control and Monitoring System Automatically uses ATMega328, temperature sensor, light sensor, proximity sensor, water level sensor, incandescent lamp, servo motor, and cooling fan.

2. This system uses an Arduino microcontroller which functions as the main controller.

3. The smartphone will provide a notification in the form of a chat message when the chicken feed has run out.

4. The RTC (Real Time Clock) module works based on actual time so it is very effective and efficient to use in designing a smart chicken coop control and monitoring system automatically with Smartphone notifications

\section{REFERENCES}

Irawan Agus DKK, 2017, Jurnal Positif, Volume 3, No.2, 2017, Banjarmasin.

Lestari Kurnia Cahya dan Amri Arni Muarifah, 2020, Sistem Informasi Akuntansi, Universitas Qomaruddin Gresik.

Nur Rusdi DKK, 2018, Perancangan Mesin-mesin Industri, Yogyakarta : Deepublish 2018.

Sari Fitri Ayu Nia Permata, 2018, Volume 2, No. 2 Oktober 2018 ISSN.2349-0222, Panam 2018.

Sawitri Yuli DKK, 2019, Dampak Penggunaan Smartphone Terhadap Perkembangan Anak Usia Dini, Kabupaten Banyumas 2019.

S Mulyani, 2017, Metode Analisis dan Perancangan Sistem, Abdi Sistematika.

Syarifuddin \& Romisyah, 2020, Jurnal Tikar Volume 1. No. 1, Januari 2020, Universitas Karimun 2020.

Putra Wirahadinata Indra DKK, 2021, Jurnal Tikar Volume 2, No. 1, Januari 2021, Universitas Karimun.

Wood David, 2019, Dampak Penggunaan Smartphone Terhadap Perkembangan Anak Usia Dini, Kabupaten Banyumas 2019.

Rifan Muhammad, 2019, Modul Sensor: Kontrol Digital dan IoT, Penerbit Muhammad Rifan.

Mochamad Fajar Wicaksono, 2019, Aplikasi Arduino dan Sensor disertai 32 proyek dan 5 proyek Robot, Informatika Bandung, Bandung.

Sidauruk, 2017, Impelemtasi Mikrokontroler Atmega 8535 Berbasis Sensor Ultrasonik Untuk proteksi Keamanan Terpadu, Sidauruk, Riki Ardi Yosua, Simamora dan Marlindia Ike Sari, Converensi Nasional ICT-M Politeknik Telkom 389-395.

Mustaziri, DKK, 2020, Informatika No.1 Vol 4 ISSN : 28007-5266, Palembang.

Destiarini, Kumara W Pius, 2019, Robot Line Pollower Berbasis Mikrokontroler Arduino Uno Atmega 328, Jurnal Informatika, Volume 5 No.1, Januari/Juni 2019 ISSN : 2407-1730. 
Setyaningsih Erni, DKK, 2017, Penggunaan Sensor Photodioda sebagai Sistem Deteksi Api pada Wahana Terbang Vertical Take Off Landing (VTOL), Jurnal Teknik Elektro Vol.9 No.2 Juni-Desember 2017 P-ISSN 1411-0059 EISSN 2549-1571, Semarang.

Dwinata I Febyano, DKK, 2019, Aplikasi Sensor Cahaya BH1750 Sebagai Sistem Pendeteksi Longsor Berbasis Pergeseran Tanah, Lampung 